\title{
Ideas and perspectives: Development of nascent autotrophic carbon fixation systems in various redox conditions of the fluid degassing on early Earth
}

\author{
Sergey A. Marakushev and Ol'ga V. Belonogova \\ Institute of Problems of Chemical Physics, Russian Academy of Sciences, Academician Semenov Avenue 1, \\ Chernogolovka, Moscow Oblast, 142432, Russia
}

Correspondence: Sergey A. Marakushev (shukaram@yandex.ru, marak@cat.icp.ac.ru)

Received: 18 June 2018 - Discussion started: 30 August 2018

Revised: 2 April 2019 - Accepted: 4 April 2019 - Published: 29 April 2019

\begin{abstract}
The origin and development of the primary autotrophic metabolism on early Earth were influenced by the two main regimes of degassing of the Earth - reducing (predominance $\left.\mathrm{CH}_{4}\right)$ and oxidative $\left(\mathrm{CO}_{2}\right)$. Among the existing theories of the autotrophic origin of life in hydrothermal environments, $\mathrm{CO}_{2}$ is usually considered to be the carbon source for nascent autotrophic metabolism. However, the ancestral carbon used in metabolism may have been derived from $\mathrm{CH}_{4}$ if the outflow of magma fluid to the surface of the Earth consisted mainly of methane. In such an environment, the primary autotrophic metabolic systems had to be methanotrophic. Due to the absence of molecular oxygen in the Archean conditions, this metabolism would have been anaerobic; i.e., oxidation of methane must be realized by inorganic high-potential electron acceptors. In light of the primacy and prevalence of $\mathrm{CH}_{4}$-dependent metabolism in hydrothermal systems of the ancient Earth, we propose a model of carbon fixation where the methane is fixed or transformed in a sequence of reactions in an autocatalytic methane-fumarate cycle. Nitrogen oxides are thermodynamically the most favorable among possible oxidants of methane; however, even the activity of oxygen created by mineral buffers of iron in hydrothermal conditions is sufficient for methanotrophic acetogenesis. The hydrothermal system model is considered in the form of a phase diagram, which demonstrates the area of redox and $P$ and $T$ conditions favorable for the development of the primary methanotrophic metabolism.
\end{abstract}

1 Deep methane degassing of the early Earth

The deep hydrocarbon generation in seismically active satellites manifested as the significant concentrations of hydrocarbons, including methane on their surface. For example, there is a prevalence of methane on Titan and Enceladus (the satellites of Saturn; Tobie et al., 2006; Bouquet et al., 2015) and on Europa (the satellite of Jupiter; e.g., Russell et al., 2017). Additionally, high concentrations of methane are assumed to be present on early Mars (Oehler and Etiope, 2017).

On Earth, methane and other hydrocarbons are generated in magma chambers, are carried by fluids to the surface through volcanic processes and are trapped in the gasliquid inclusions during the mineral formation. This has been observed in the quartz-methane amygdaline inclusions that occur in the form of relics present in metamorphicbasaltic rocks of Greenland that were dated to 3.8 billion years (Touret, 2003). The inclusion of hydrocarbons and reduced organic compounds in Archean quartz (Touret, 2003; Schreiber et al., 2017) indicates a sufficiently reductive environment at this time. There is evidence that the Archean atmosphere was enriched in hydrogen and methane (Tian et al., 2005; Zahnle et al., 2019), but the oxidation state of magma sources has apparently changed (Aulbach et al., 2017). According to the trace-element data of igneous zircon crustal origin (mainly Ce-based oxybarometer), it was shown that the Hadean continental crust was significantly more reduced than its modern counterpart and experienced progressive oxidation $\sim 3.6$ billion years ago (Yang et al., 2014). In addition, the oxygen activity (log units) in the Earth's crust periodically changed with regards to the quartz-magnetite-fayalite 
redox buffer from -8 to +4 in the Hadean time and from -7 to +7 in the early Archean eon. Significant fluctuations in the redox state of Archean and Hadean zircons indicate a pulsed regime of Earth degassing during this period of time, which, in our opinion, is related to impulses in the geomagnetic field (Alldredge, 1984; Larson and Olson, 1991; Aubert et al., 2010). Thus, the evolution of the Earth over a period of 4.6 billion years is determined by the impulsive degassing of its liquid core along the structures of the dislocation of its solid silicate shells (mantle and crust).

Of all the magmatic formations of the world, the alkaline magmatism is the deepest and controlled by mantle cycles (Balashov and Glaznev, 2006; Marakushev and Marakushev, 2010), and in its magma chambers, hydrocarbon substances arise. Thermodynamic calculations show the preference of deep formation and stability of hydrocarbons, which are carried in fluids to the Earth surface (temperature and pressure decreasing) and are transformed to methane (Marakushev and Marakushev, 2006). This is confirmed by the massive production of abiotic methane at $\sim 40 \mathrm{~km}$ depth (Brovarone et al., 2017) and the discovered bubbles of hydrocarbons trapped in eclogite, a metamorphic rock that forms at high pressure at a depth of at least $80 \mathrm{~km}$ (Tao et al., 2018). The gas-liquid inclusions of methane in diamond, geochemical analyses and $P-T$ experiments on the synthesis of hydrocarbons (Scott et al., 2004; Schulte et al., 2006; Kolesnikov, et al., 2009; Etiope and Sherwood Lollar, 2013; McCollom, 2013; Smit et al., 2016) also prove its deep origin.

The global mid-ocean ridge system represents a major site for outgassing of volatiles from the Earth's mantle. Methane, which was believed to have a surface origin (low-temperature serpentinization $\sim 100^{\circ} \mathrm{C}$ ), is apparently formed at depth, at temperatures of ca. $400^{\circ} \mathrm{C}$ under redox conditions characterizing intrusive rocks derived from sub-ridge melts (Mével, 2003; Wang et al., 2018). Thus, deep, alkaline-basalt magmatism (elevated alkali content, especially $\mathrm{K}_{2} \mathrm{O}$ ), in contrast to basalt-andesitic magnetism, is mainly responsible for methane degassing on the Earth's surface. With increasing alkalinity (alkaline slope) of igneous rocks, the different hydrocarbons invariably appear in fluid inclusions (Potter and Konnerup-Madsen, 2003; Nivin et al., 2005). The high content of potassium in the high-silica Hadean crust (Boehnkea et al., 2018) indicates the depth of magmatism and its hydrocarbon specificity.

The model of two-stage development of fluids (I $\leftrightarrow$ II) generated by the Earth's core via mantle magma chambers is presented in the phase diagram of the $\mathrm{C}-\mathrm{H}-\mathrm{O}$ compositions (Fig. 1). Fluids ejected from the liquid core were initially saturated with hydrogen, with oxygenic components being of minor importance. However, during the process of the Earth's silicate shell (mantle and crust) extension (associated, in our opinion, with a Hadean to Paleoarchean geodynamo; Tarduno et al., 2015), an increase in fluid permeability stimulates the selective migration of hydrogen (the most mobile component) from it. This process is responsible for hy-

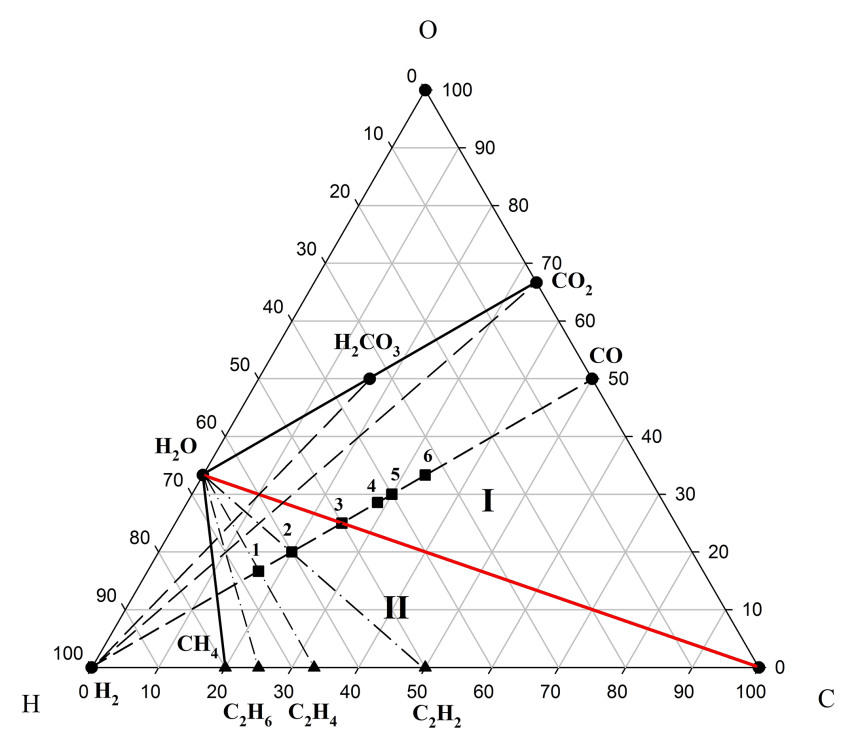

Figure 1. Two regimes of evolution of the $\mathrm{C}-\mathrm{H}-\mathrm{O}$ system on the phase diagram of its compositions. Roman numerals denote various regimes of hydrogen fluid evolution: (I) water-carbonate and (II) water-hydrocarbon solutions, separated by $\mathrm{H}_{2} \mathrm{O}-\mathrm{C}$ equilibrium (red). Parageneses (assemblages) of the initial substances $\left(\mathrm{H}_{2}, \mathrm{CO}\right.$ and $\mathrm{CO}_{2}$ ) are denoted by dashed sub-lines, while dashed-dotted lines indicate the parageneses $\left(\mathrm{C}_{2} \mathrm{H}_{6}-\mathrm{H}_{2} \mathrm{O}, \mathrm{C}_{2} \mathrm{H}_{4}-\mathrm{H}_{2} \mathrm{O}\right.$, etc.) of hydrocarbons (black triangles) with water. Black squares denote organic substances within the two component $\left(\mathrm{H}_{2}-\mathrm{CO}\right)$ subsystem: methanol (1), ethylene glycol (2), acetate (3), succinate (4), pyruvate (5) and fumarate (6).

drogen losing its leading position in ejected fluids and being fundamental to the evolution of low and normal alkalinity magmatism (Marakushev and Marakushev, 2008, 2010). In this scenario, the fractionation of chemical components in the fluid would result in rich acidic $\mathrm{CO}_{2}$ solutions (for example, $\mathrm{H}_{2}+2 \mathrm{CO}=\mathrm{H}_{2} \mathrm{O}+0.5 \mathrm{CO}_{2}+1.5 \mathrm{C}$ and $\mathrm{H}_{2} \mathrm{O}+\mathrm{CO}_{2}=\mathrm{H}_{2} \mathrm{CO}_{3}$ ). These solutions are widely observed in the composition of fluid inclusions in minerals of all igneous rocks of low and normal alkalinity. The water-carbonate regime of hydrogen fluid evolution is represented in the phase diagram (Fig. 1) as an area of thermodynamic stability (facies I) limited by $\mathrm{C}-\mathrm{CO}_{2}-\mathrm{H}_{2} \mathrm{O}$ paragenesis.

The transition to compression of silicate shells prevents hydrogen migration from fluids and stimulates the production of hydrocarbons within them; for example, consider the following reactions: $3 \mathrm{H}_{2}+\mathrm{CO}=\mathrm{H}_{2} \mathrm{O}+\mathrm{CH}_{4}$ and $5 \mathrm{H}_{2}+$ $2 \mathrm{CO}=2 \mathrm{H}_{2} \mathrm{O}+\mathrm{C}_{2} \mathrm{H}_{6}$ (Fig. 1; facies II; reducing conditions). The hydrogen in a reaction like $4 \mathrm{H}_{2}+\mathrm{H}_{2} \mathrm{CO}_{3}=3 \mathrm{H}_{2} \mathrm{O}+\mathrm{CH}_{4}$ destroys the acid components in fluids, and this determines the alkaline slope in the development of magmatism. This is a two-stage model of the development of the $\mathrm{C}-\mathrm{H}-\mathrm{O}$ system (I $\leftrightarrow$ II), which depends on the composition of Earth's core fluids and their transformations in magma chambers. 
The existing theories on the origin of autotrophic life mainly identify carbon dioxide as the unique carbon source for metabolism. This autotrophic metabolism should have originated at a high partial pressure of $\mathrm{CO}_{2}$ in the environment (paragenesis $\mathrm{CO}_{2}+\mathrm{H}_{2} \mathrm{O}$; Fig. 1; facies I). We assume that in geodynamic regime II $\left(\mathrm{CH}_{4}+\mathrm{H}_{2} \mathrm{O}\right.$ paragenesis $)$, carbon ancestral metabolism could use methane as a carbon source if the flow of free energy from the geochemical environment is coupled with biomass formation reactions. Perhaps these different regimes of fluid degassing determined the physicochemical conditions of the ambient environment, which, in turn, provided an opportunity for the emergence and development of various systems of ancient autotrophic metabolism. In regime II (Fig. 1), methane and other hydrocarbons could be substrates of the emerging autotrophic metabolism.

The above geochemical and petrological data indicate highly heterogeneous redox conditions between the presentday Earth and conditions that periodically arose on the early Earth. We consider that the anaerobic reductive geochemical conditions of the Archean played a decisive role in the origin and development of carbon and energy metabolism, which were vastly different from those observed in the tops of the branches of the modern phylogenetic tree of prokaryotes. Most metabolically anaerobic chemoautotrophic organisms are either extinct or strongly limited to narrow anoxic ecological niches. Lateral gene transfer and subsequent phylogenetic divergence erased most evolutionary information recorded in ancestral prokaryotic genomes (Martin et al., 2016).

\section{Anaerobic oxidation of methane}

The study of anaerobic oxidation of methane (AOM) in modern oxygen-free environments (marine sedimentary rocks, gas hydrates, mud volcanoes, black smokers and hydrocarbon seeps) has increased in recent years. This direction was sparked by the discovery of anaerobic methanotrophic archaea (Hinrichs et al., 1999) and, subsequently, their structural consortia with sulfate-reducing bacteria (Knittel and Boetius, 2009). A similar consortium was later discovered in archaea species that function in chemical conjunction with the bacterium Candidatus Methylomirabilis oxyfera, which itself can independently couple AOM with denitrification (Ettwig et al., 2010; Haroon et al., 2013). Furthermore, the microbiological AOM was recently shown to be directly associated with the reduction of iron and manganese compounds and minerals (Beal., 2009; Ettwig et al., 2016; Oni and Friedrich, 2017; He et al., 2018), as, for example, in the reaction $\mathrm{CH}_{4}+8 \mathrm{Fe}^{3+}+2 \mathrm{H}_{2} \mathrm{O} \rightarrow \mathrm{CO}_{2}+8 \mathrm{Fe}^{2+}+8 \mathrm{H}^{+}$ $\left(\Delta G^{0^{\prime}}=-454 \mathrm{~kJ} \mathrm{~mol}^{-1} \mathrm{CH}_{4}\right)$.
Recent studies have suggested that both archaea (ANME2d; Haroon et al., 2013) and bacteria (Methylobacter; Martinez-Cruz et al., 2017), without partners, may themselves be versatile methanotrophs capable of using different oxidants as electron acceptors under different environmental conditions. AOM occurs by the reversal canonical methanogenesis pathway (Timmers et al., 2017), and, perhaps, the evolution of life periodically includes forward or reverse pathways depending on the substrate (methanogenmethanotroph "switch back" - McGlynn, 2017). For example, nickel enzyme purified from methanogenic archaea can catalyze the oxidation of methane to methyl coenzyme $\mathrm{M}\left(\mathrm{CH}_{4}+\mathrm{CoM}-\mathrm{S}-\mathrm{S}-\mathrm{CoB} \rightarrow \mathrm{CH}_{3}-\mathrm{S}-\mathrm{CoM}+\mathrm{HS}-\right.$ $\mathrm{CoB} ; \Delta G^{0^{\prime}}=30 \pm 10 \mathrm{~kJ}$ ), which is the reverse reaction of methyl coenzyme $M$ reductase (Scheller et al., 2010). In general, methanotrophs and methylotrophs use different but often interrelated pathways of carbon fixation (Smejkalová et al., 2010). Newly described methanotrophic anaerobic prokaryotes are frequently discovered in various extreme environmental conditions (Semrau et al., 2008), underscoring the functional and phylogenetic diversity of this group. The search for relict forms of anaerobic methanotrophic metabolism continues.

In 2013, Wolfgang Nitschke and Michael Russell described the possibility of methane assimilation as the sole source of carbon for primordial metabolism (Nitschke and Russell, 2013). They suggested that methanotrophy and not methanogenesis may have been the founding metabolism in the first protocells and presented a model of methanotrophic acetogenesis in which methane, as the carbon source, is assimilated into the biomimetic analogue of the modern reverse acetyl-CoA pathway. The proposed methane oxidant in this pathway of $\mathrm{CH}_{4}$ fixation was nitric oxide (NO), formed via nitrate-nitrite transformation ("denitrifying methanotrophic acetogenesis"; Russell and Nitschke, 2017). The authors consider that the process of low-temperature harzburgite (ophiolites) hydrothermal serpentinization in the presence of carbon oxides served as the main source of methane. Nevertheless, Wang et al. (2018) argue that there is another unified deep high-temperature process of making methane for these hydrothermal areas.

In the absence of oxygen, the methane oxidation requires electron acceptors with a high redox potential, such as nitrate, manganese (IV), iron (III) and sulfate. Thermodynamic calculations of anaerobic methanotrophic acetogenesis reactions in aqueous hydrothermal conditions that require oxidized compounds such as sulfur, nitrogen and iron are considered in Table 1. For example, the free energy of the reaction $\mathrm{CH}_{4}+6 \mathrm{Fe}_{2} \mathrm{O}_{3}=0.5 \mathrm{CH}_{3} \mathrm{COOH}+\mathrm{H}_{2} \mathrm{O}+4 \mathrm{Fe}_{3} \mathrm{O}_{4}$ at $473 \mathrm{~K}$ is equal to the sum of the free energy of products formation minus the sum of free energy of the reactant formation at the same temperature $\left(\Delta G_{473}^{0}=\left(0,5 \Delta G_{\mathrm{CH}_{3} \mathrm{COOH}}^{0}+\Delta G_{\mathrm{H}_{2} \mathrm{O}}^{0}+\right.\right.$ $\left.\left.4 \Delta G_{\mathrm{Fe}_{3} \mathrm{O}_{4}}^{0}\right)-\left(\Delta G_{\mathrm{CH}_{4}}^{0}+6 \Delta G_{\mathrm{Fe}_{2} \mathrm{O}_{3}}^{0}\right)=-6.49 \mathrm{~kJ} \mathrm{~mol}^{-1}\right)$. 
Table 1. Free Gibbs energy of aqueous reactions of anaerobic methanotrophic acetogenesis at 298 and $473 \mathrm{~K}$ at the saturated vapor pressure $\left(P_{\mathrm{SAT}}\right)$. The oxidized and reduced states of oxidant in the reaction are conditionally called the redox pairs. The oxidation of methane to fully ionized and non-ionized forms of acetate is presented. Value of $\Delta G_{\mathrm{T}}^{0}$ at 298 and $473 \mathrm{~K}$ indicates the advantage of the reactions at low $(L)$ or high $(H)$ temperatures. Free energies of aqueous substances formation at $P_{\mathrm{SAT}}$ (Amend and Shock, 2001) were used in calculations.

\begin{tabular}{|c|c|c|c|}
\hline Redox pairs of nitrogen & $\Delta G_{298}^{0} \mathrm{~kJ} \mathrm{~mol} \mathrm{CH} 4$ & $\Delta G_{473}^{0} \mathrm{~kJ} \mathrm{~mol} \mathrm{CH} 4$ & \\
\hline $\mathrm{CH}_{4}+2 \mathrm{NO}=0.5 \mathrm{CH}_{3} \mathrm{COOH}+\mathrm{H}_{2} \mathrm{O}+\mathrm{N}_{2}$ & -586.78 & -563.18 & $L$ \\
\hline $\mathrm{CH}_{4}+2 \mathrm{NO}=0.5 \mathrm{CH}_{3} \mathrm{COO}^{-}+0,5 \mathrm{H}^{+}+\mathrm{H}_{2} \mathrm{O}+\mathrm{N}_{2}$ & -573.39 & -538.33 & \\
\hline $\mathrm{CH}_{4}+4 \mathrm{NO}=0.5 \mathrm{CH}_{3} \mathrm{COOH}+\mathrm{H}_{2} \mathrm{O}+2 \mathrm{~N}_{2} \mathrm{O}$ & -582.32 & -535.87 & $L$ \\
\hline $\mathrm{CH}_{4}+4 \mathrm{NO}=0.5 \mathrm{CH}_{3} \mathrm{COO}^{-}+0,5 \mathrm{H}^{+}+\mathrm{H}_{2} \mathrm{O}+2 \mathrm{~N}_{2} \mathrm{O}$ & -568.93 & -511.02 & \\
\hline $\mathrm{CH}_{4}+4 \mathrm{HNO}_{2}=0.5 \mathrm{CH}_{3} \mathrm{COOH}+3 \mathrm{H}_{2} \mathrm{O}+4 \mathrm{NO}$ & -264.46 & -320.79 & $H$ \\
\hline $\mathrm{CH}_{4}+4 \mathrm{NO}_{2}^{-}+3.5 \mathrm{H}^{+}=0.5 \mathrm{CH}_{3} \mathrm{COO}^{-}+4 \mathrm{NO}+3 \mathrm{H}_{2} \mathrm{O}$ & -324.71 & -398.7 & \\
\hline $\mathrm{CH}_{4}+2 \mathrm{HNO}_{3}=0.5 \mathrm{CH}_{3} \mathrm{COOH}+\mathrm{H}_{2} \mathrm{O}+2 \mathrm{HNO}_{2}$ & -295.16 & -286.35 & $L$ \\
\hline $\mathrm{CH}_{4}+2 \mathrm{NO}_{3}^{-}=0.5 \mathrm{CH}_{3} \mathrm{COO}^{-}+2 \mathrm{NO}_{2}^{-}+\mathrm{H}_{2} \mathrm{O}+0.5 \mathrm{H}^{+}$ & -230.07 & -217.58 & \\
\hline $\mathrm{CH}_{4}+1.33 \mathrm{HNO}_{3}=0.5 \mathrm{CH}_{3} \mathrm{COOH}+1.67 \mathrm{H}_{2} \mathrm{O}+1.33 \mathrm{NO}$ & -286.41 & -299.38 & $H$ \\
\hline $\mathrm{CH}_{4}+1.33 \mathrm{NO}_{3}^{-}+0.83 \mathrm{H}^{+}=0.5 \mathrm{CH}_{3} \mathrm{COO}^{-}+1.33 \mathrm{NO}+1.67 \mathrm{H}_{2} \mathrm{O}$ & -263.12 & -304.34 & \\
\hline $\mathrm{CH}_{4}+0.8 \mathrm{HNO}_{3}=0.5 \mathrm{CH}_{3} \mathrm{COOH}+1.4 \mathrm{H}_{2} \mathrm{O}+0.4 \mathrm{~N}_{2}$ & -405.67 & -403.98 & $L$ \\
\hline $\mathrm{CH}_{4}+0.8 \mathrm{NO}_{3}^{-}+0.3 \mathrm{H}^{+}=0.5 \mathrm{CH}_{3} \mathrm{COO}^{-}+0.4 \mathrm{~N}_{2}+1.4 \mathrm{H}_{2} \mathrm{O}$ & -386.33 & -382.11 & \\
\hline \multicolumn{4}{|l|}{ Redox pairs of iron (mineral buffers) } \\
\hline $\mathrm{CH}_{4}+6 \mathrm{Fe}_{2} \mathrm{O}_{3}=0.5 \mathrm{CH}_{3} \mathrm{COOH}+\mathrm{H}_{2} \mathrm{O}+4 \mathrm{Fe}_{3} \mathrm{O}_{4}$ & 11.84 & -6.49 & $H$ \\
\hline $\mathrm{CH}_{4}+6 \mathrm{Fe}_{2} \mathrm{O}_{3}=0.5 \mathrm{CH}_{3} \mathrm{COO}^{-}+0,5 \mathrm{H}^{+}+\mathrm{H}_{2} \mathrm{O}+4 \mathrm{Fe}_{3} \mathrm{O}_{4}$ & 25.23 & 18.36 & \\
\hline $\mathrm{CH}_{4}+1.5 \mathrm{FeS}_{2}+0.5 \mathrm{Fe}_{3} \mathrm{O}_{4}=0.5 \mathrm{CH}_{3} \mathrm{COOH}+\mathrm{H}_{2} \mathrm{O}+3 \mathrm{FeS}$ & 44.65 & 28.85 & $H$ \\
\hline $\mathrm{CH}_{4}+1.5 \mathrm{FeS}_{2}+0.5 \mathrm{Fe}_{3} \mathrm{O}_{4}=0.5 \mathrm{CH}_{3} \mathrm{COO}^{-}+0,5 \mathrm{H}^{+}+\mathrm{H}_{2} \mathrm{O}+3 \mathrm{FeS}$ & 58.04 & 53.7 & \\
\hline $\mathrm{CH}_{4}+2 \mathrm{Fe}_{3} \mathrm{O}_{4}+3 \mathrm{SiO}_{2}=0.5 \mathrm{CH}_{3} \mathrm{COOH}+\mathrm{H}_{2} \mathrm{O}+3 \mathrm{Fe}_{2} \mathrm{SiO}_{4}$ & 57.23 & 16.19 & $H$ \\
\hline $\mathrm{CH}_{4}+2 \mathrm{Fe}_{3} \mathrm{O}_{4}+3 \mathrm{SiO}_{2}=0.5 \mathrm{CH}_{3} \mathrm{COO}^{-}+0,5 \mathrm{H}^{+}+\mathrm{H}_{2} \mathrm{O}+3 \mathrm{Fe}_{2} \mathrm{SiO}_{4}$ & 70.62 & 41.04 & \\
\hline \multicolumn{4}{|l|}{ Redox pair of sulfur } \\
\hline $\mathrm{CH}_{4}+0.5 \mathrm{H}_{2} \mathrm{SO}_{4}=0.5 \mathrm{CH}_{3} \mathrm{COOH}+\mathrm{H}_{2} \mathrm{O}+0.5 \mathrm{H}_{2} \mathrm{~S}$ & -42.57 & -69.93 & $H$ \\
\hline $\mathrm{CH}_{4}+0.5 \mathrm{SO}_{4}^{-2}+0,5 \mathrm{H}^{+}=0.5 \mathrm{CH}_{3} \mathrm{COO}^{-}+\mathrm{H}_{2} \mathrm{O}+0.5 \mathrm{H}_{2} \mathrm{~S}$ & -29.18 & -45.07 & \\
\hline \multicolumn{4}{|l|}{ Carboxy-methano acetogenesis } \\
\hline $\mathrm{CH}_{4}+\mathrm{CO}_{2}+2 \mathrm{NO}+2 \mathrm{H}_{2}=\mathrm{CH}_{3} \mathrm{COOH}+\mathrm{N}_{2}+2 \mathrm{H}_{2} \mathrm{O}$ & -671.53 & -620.83 & $L$ \\
\hline $\mathrm{CH}_{4}+\mathrm{HCO}_{3}^{-}+2 \mathrm{NO}+2 \mathrm{H}_{2}=\mathrm{CH}_{3} \mathrm{COO}^{-}+\mathrm{N}_{2}+3 \mathrm{H}_{2} \mathrm{O}$ & -680.97 & -636.35 & \\
\hline $\mathrm{CH}_{4}+0.5 \mathrm{CO}_{2}+6 \mathrm{Fe}_{2} \mathrm{O}_{3}+\mathrm{H}_{2}=0.75 \mathrm{CH}_{3} \mathrm{COOH}+4 \mathrm{Fe}_{3} \mathrm{O}_{4}+1.5 \mathrm{H}_{2} \mathrm{O}$ & -30.54 & -35.34 & $H$ \\
\hline $\mathrm{CH}_{4}+0.5 \mathrm{HCO}_{3}^{-}+6 \mathrm{Fe}_{2} \mathrm{O}_{3}+\mathrm{H}_{2}=0.75 \mathrm{CH}_{3} \mathrm{COO}^{-}+4 \mathrm{Fe}_{3} \mathrm{O}_{4}+2 \mathrm{H}_{2} \mathrm{O}+0,25 \mathrm{H}^{+}$ & -28.56 & -30.64 & \\
\hline $\mathrm{CH}_{4}+\mathrm{CO}_{2}=\mathrm{CH}_{3} \mathrm{COOH}$ & 24.27 & 39.89 & $L$ \\
\hline $\mathrm{CH}_{4}+\mathrm{HCO}_{3}^{-}=\mathrm{CH}_{3} \mathrm{COO}^{-}+\mathrm{H}_{2} \mathrm{O}$ & 14.83 & 24.41 & \\
\hline \multicolumn{4}{|l|}{ Carboxy acetogenesis } \\
\hline $\mathrm{CO}_{2}+2 \mathrm{H}_{2}=0,5 \mathrm{CH}_{3} \mathrm{COOH}+\mathrm{H}_{2} \mathrm{O}$ & -84.75 & -57.65 & $H$ \\
\hline $\mathrm{HCO}_{3}^{-}+2 \mathrm{H}_{2}+0,5 \mathrm{H}^{+}=0,5 \mathrm{CH}_{3} \mathrm{COO}^{-}+2 \mathrm{H}_{2} \mathrm{O}$ & -107.58 & -98.01 & \\
\hline
\end{tabular}

It is obvious that methane oxidation with nitrogen oxide compounds is thermodynamically very favorable, compared to oxidants such as sulfate, magnetite and hematite. The acetogenesis reactions are energetically more preferable under acidic hydrothermal conditions (the protonated compounds). The change in the free energy with temperature change indicates whether the reaction displays a thermodynamic preference for low-temperature $(L)$ or high-temperature $(H)$ conditions. The reactions of methane with sulfate and iron oxides is the most thermodynamically favorable with increasing temperatures (decreasing $\Delta G_{\mathrm{r}}^{0}$ ), whereas the reactions with nitrogen oxides have different directions. The methane fixation is an energetically more favorable process than $\mathrm{CO}_{2}$ fixation. For example, in aerobic acetogenesis $\left(\mathrm{CH}_{4}+\right.$ $\left.\mathrm{O}_{2}=0,5 \mathrm{CH}_{3} \mathrm{COOH}+\mathrm{H}_{2} \mathrm{O}\right)$, more free energy is released in the methane fixation reaction $\left(\Delta G_{298}^{0}=-417.35 \mathrm{~kJ} \mathrm{~mol}^{-1}\right.$ under standard conditions; aqueous constants from Amend and Shock, 2001) than in the process of $\mathrm{CO}_{2}$ fixation $\left(\mathrm{CO}_{2}+\right.$ $\left.2 \mathrm{H}_{2}=0,5 \mathrm{CH}_{3} \mathrm{COOH}+\mathrm{H}_{2} \mathrm{O} ; \Delta G_{298}^{0}=-84.75 \mathrm{~kJ}\right)$.

The most favorable reaction, $\mathrm{CH}_{4}+$ $2 \mathrm{NO}=0,5 \mathrm{CH}_{3} \mathrm{COOH}+\mathrm{H}_{2} \mathrm{O}+\mathrm{N}_{2}$ (Table 1), can be represented as a model of methanotrophic acetogenesis, which is part of the reverse acetyl-CoA pathway. The second part of this path is the reaction of 
$\mathrm{CO}_{2}$ reduction: $\mathrm{CO}_{2}+2 \mathrm{H}_{2}=0,5 \mathrm{CH}_{3} \mathrm{COOH}+\mathrm{H}_{2} \mathrm{O}$. In sum, this is a very thermodynamically favorable pathway of carbon fixation in the form of $\mathrm{CH}_{4}$ and $\mathrm{CO}_{2}$ : $\mathrm{CH}_{4}+\mathrm{CO}_{2}+2 \mathrm{NO}+2 \mathrm{H}_{2}=\mathrm{CH}_{3} \mathrm{COOH}+\mathrm{N}_{2}+2 \mathrm{H}_{2} \mathrm{O}$.

The different stoichiometry of acetogenesis was observed in the archaea Methanosarcina acetivorans, when methane oxidation was associated with the reduction of iron (III; Soo et al., 2016). A reaction is proposed in which four methane molecules are oxidized and two $\mathrm{CO}_{2}$ molecules are reduced to form three acetate molecules. Increasing the ratio of $\mathrm{CH}_{4}$ to $\mathrm{CO}_{2}$ $\left(4 \mathrm{CH}_{4}+2 \mathrm{CO}_{2}+24 \mathrm{Fe}_{2} \mathrm{O}_{3}+4 \mathrm{H}_{2}=3 \mathrm{CH}_{3} \mathrm{COOH}+6 \mathrm{H}_{2} \mathrm{O}\right.$ $\left.+16 \mathrm{Fe}_{3} \mathrm{O}_{4}\right)$ makes the process of anaerobic acetogenesis more thermodynamically favorable (Table 1; carboxymethano acetogenesis).

The last universal common ancestor (LUCA) era apparently proceeded in an environment with high $\mathrm{CO}_{2}$ partial pressure, whereas the pre-LUCA period proceeded in a reducing environment with a significant availability of methane. The following question thus arises: was this ancestral reverse acetyl-CoA relic pathway the only metabolic $\mathrm{CH}_{4}$ fixation system, or were there other protobiochemical mechanisms for the assimilation of carbon?

In addition to the acetyl-CoA pathway, autocatalytic $\mathrm{CO}_{2}$ fixation cycles have been suggested as the first metabolic autocatalytic systems on early Earth (Wächtershäuser, 1990; Smith and Morowitz, 2004; Marakushev and Belonogova, 2009, 2013; Fuchs, 2011; Braakman and Smith, 2012, 2013). These include an autocatalytic reductive tricarboxylic acid (rTCA) cycle (reverse citrate cycle or Arnon-Buchanan cycle), a 3-hydroxypropionate cycle, a 3-hydroxypropionate/4-hydroxybutyrate cycle, a reductive dicarboxylate/4-hydroxybutyrate cycle and a reducing pentose phosphate (Calvin-Benson-Bassham) cycle. The defined sequences of intermediates of these cycles are modules such that their combination can create a variety of metabolic systems, including the specific pathways of carbon fixation (Lorenz et al., 2011; Marakushev and Belonogova, 2010, 2015; Braakman and Smith, 2012, 2013). To be considered a possible metabolic alternative, assimilating methane through autocatalytic cycle intermediates must satisfy the fundamental requirements of thermodynamics.

\section{The proposed methane-fumarate cycle}

Based on the hypothesis of primordial anaerobic methanotrophic metabolism origin, we assume that some components and modules of the metabolic cycles (carboxylic and keto acids and their associations - parageneses) may also be relicts of ancient methanotrophic metabolism. One of the few known reactions of $\mathrm{CH}_{4}$ fixation is the formation of 2-methylsuccinate as a result of the reaction fumarate $+\mathrm{CH}_{4} \rightarrow$ 2-methylsuccinate (Thauer and Shima, 2008; Haynes and Gonzalez, 2014), and fumarate addi- tion has been widely proposed as an initial step in the anaerobic oxidation of both aromatic and aliphatic hydrocarbons (Musat, 2015). The reaction of methane with fumarate satisfies the "minimal energy requirements" for autotrophic growth (Beasley and Nanny, 2012), and we consider the possibility of its participation in nascent autotrophic metabolism. We propose a simplified model of the methanefumarate (MF) cycle (Fig. 2), which could have originated in the reductive Archean hydrothermal systems at a high partial pressure of endogenous methane (facies II; Fig. 1). The cycle is initiated by the reaction of fumarate + methane $\rightarrow 2$ methylsuccinate. In the hydration and dehydrogenation or anaerobic oxidation reactions, 2-methylsuccinate is converted to citramalate, which is disproportionated to acetate and pyruvate with cleavage of a carbon-carbon bond. Pyruvate is an important "hub" metabolite that is a precursor for amino acids, carbohydrates, cofactors and lipids in an extant metabolic network. The following carbon assimilation reaction in the form of $\mathrm{CO}_{2}$ with the formation of oxaloacetate is a biomimetic analogue of the rTCA cycle reaction. An $\alpha$-carboxylation of pyruvate is a critical anabolic pathway in modern biochemistry, which resupplies rTCA cycle intermediates. Oxaloacetate is transformed into fumarate in the reactions of the citrate cycle intermediates. The resulting fumarate assimilates methane and begins a new MF cycle; in one turnover of which, an acetate molecule is formed from methane and carbon dioxide molecules: $\mathrm{CH}_{4}+\mathrm{CO}_{2}=\mathrm{CH}_{3} \mathrm{COOH}$ (Table 1). The nonenzymatic flow of some reaction sequences of the rTCA cycle, such as oxaloacetate $\rightarrow$ malate $\rightarrow$ fumarate $\rightarrow$ succinate, has been recently experimentally confirmed (Muchowska et al., 2017).

Transformation of fumarate into 2-methylsuccinate introduces into the cycle five-carbon intermediates, such as citramalate and mesaconate, functioning, for example, in the reductive 3-hydroxypropionate $\mathrm{CO}_{2}$ fixation cycle. The autocatalytic nature of the cycle derives from the branching point associated with citramalate cleavage and can be shown by the example of doubling the intermediate as in the following reaction: $\mathrm{C}_{4} \mathrm{H}_{6} \mathrm{O}_{5}$ (malate) $+1,5 \mathrm{CH}_{4}+$ $2,5 \mathrm{CO}_{2}=2 \mathrm{C}_{4} \mathrm{H}_{6} \mathrm{O}_{5}$ (two malates). This type of autotrophic metabolism, as in the case of the acetyl-CoA pathway, can be defined as carboxy-methanotrophic acetogenesis. As it happened with the archean reverse acetyl-CoA pathway (e.g., Soo et al., 2016), methanotrophy should probably be combined with the carboxylation process; therefore nature had to look for all possible sources of carbon dioxide. The problem of the most energetically unfavorable reaction of 2methylsuccinate transformation into citramalate $\left(\Delta G_{298}^{0}=\right.$ $96.57 \mathrm{~kJ}$; Table 2a) can be solved by using oxidants, such as oxides of nitrogen and iron (Fig. 2, inset). NO is the strongest oxidant, but the reaction with $\mathrm{Fe}_{2} \mathrm{O}_{3}$ is also favorable at physiological temperatures.

The reversibility of the reactions in the rTCA cycle is mainly determined by the equilibrium of fumarate $+\mathrm{H}_{2}=$ succinate $\quad\left(\Delta G_{298}^{0}=-102.24\right.$, 


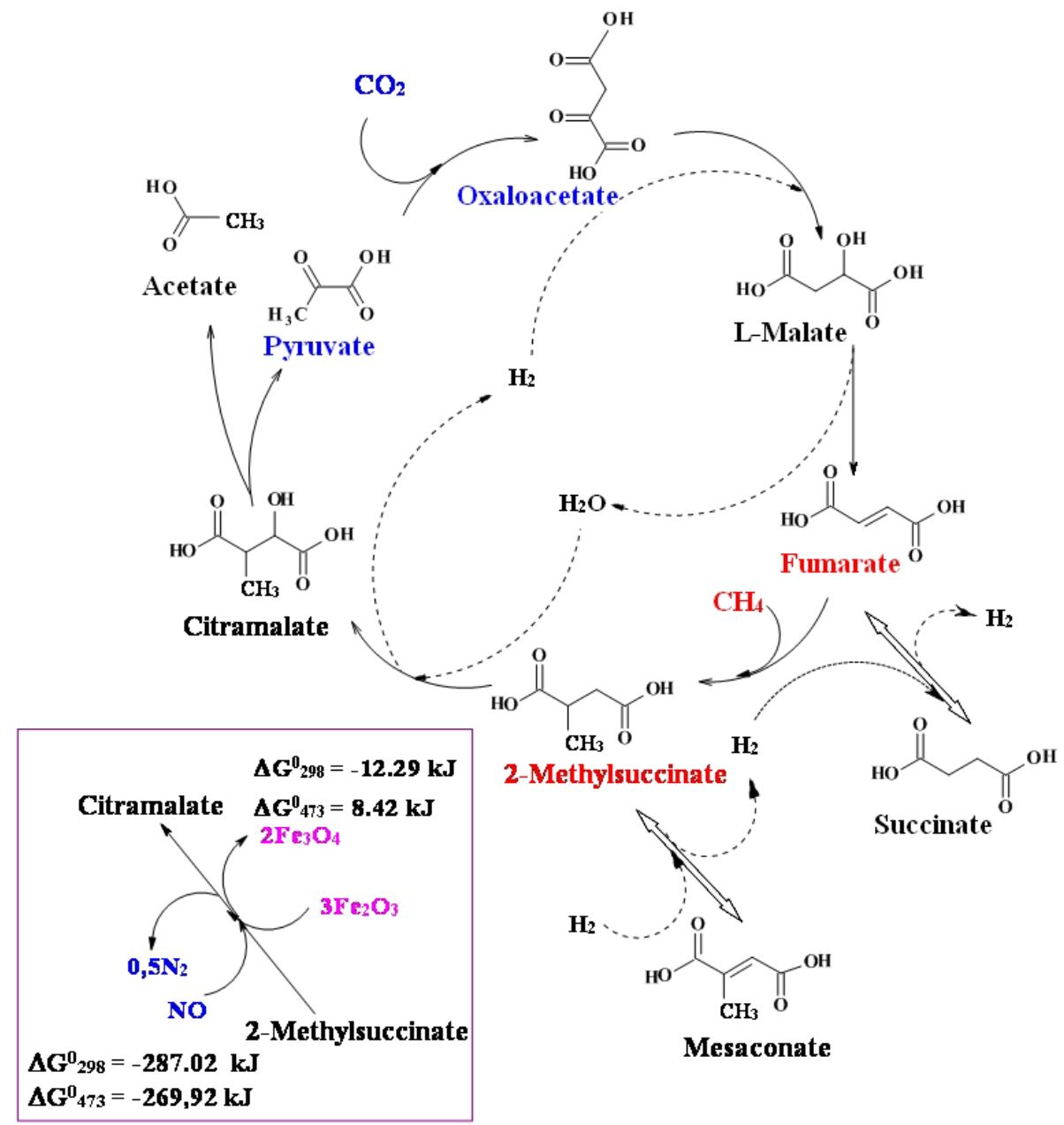

Figure 2. The scheme of the proposed methane-fumarate (MF) cycle. Carbon from methane is introduced into the fumarate (marked by red), and that from $\mathrm{CO}_{2}$ is introduced into the pyruvate (marked by blue) with the formation of a $\mathrm{C}-\mathrm{C}$ bond. The reaction sequence pyruvate $\rightarrow$ oxaloacetate $\rightarrow$ malate $\rightarrow$ fumarate $\rightarrow$ succinate is part of the reductive tricarboxylic acid (rTCA) cycle, an enzyme-free archaic version which is proposed as the basis of ancient autotrophic metabolism (Wächtershäuser 1990; Smith and Morowitz, 2004). The inset shows options for the oxidative transformation of 2-methylsuccinate to citramalate with hematite $\left(\mathrm{Fe}_{2} \mathrm{O}_{3}\right)$ and nitric oxide (NO) as oxidants. The chemical potential of hydrogen in the environment determines the equilibrium shift in the reactions succinate $\leftrightarrow$ fumarate and 2 -methylsuccinate $\leftrightarrow$ mesaconate.

$\Delta G_{473}^{0}=-88.88 \mathrm{~kJ}$; Table 2a). The change in the direction of electron flow therein is determined by the chemical potential of hydrogen (Marakushev and Belonogova, 2009), and therefore, different protometabolic cycles could be formed, for example, the oxidative citrate and reductive 3-hydroxypropionate cycles (succinate $\rightarrow$ fumarate), the rTCA cycle (fumarate $\rightarrow$ succinate), or the proposed $\mathrm{CH}_{4}$ fixation cycle (succinate $\rightarrow$ fumarate $\rightarrow 2$-methylsuccinate).

The anaerobic methane-oxidizing branch of the cycle represents the transformation of fumarate to pyruvate and acetate. The free energies of these reactions with various inorganic oxidizing agents at 298 and $473 \mathrm{~K}$ are given in Table 2b. Assimilation of $\mathrm{CH}_{4}$ in the oxidizing branch of the cycle (Fig. 2a) demonstrates highly favorable thermodynamics with all redox pairs of nitrogen. The same reaction with the iron redox pair becomes more favorable at an increasing temperature. Reactions with iron mineral buffers (Table 2a) are closer to the equilibrium state, which ultimately determines the possibilities of primordial cycle flow in the forward or reverse directions (development of methanogenesis or methanotrophic acetogenesis). An analysis of the oldest known association of microfossils suggests that methanecycling methanogen-methanotroph communities were a significant component of the Earth's early biosphere (Schopf et al., 2017). It is possible that high-methane partial pressure, which existed in a geodynamic regime of high endogenous methane flow in ancient Earth, promoted the formation of various versions of carbon-assimilating systems.

Methyl group formation by the oxidation of methane is limited by kinetics because the dissociation energy of 
Table 2. The free energy of reactions of MF cycle (a) and reactions of its anaerobic oxidative branch (b) with different oxidants at 298 and $473 \mathrm{~K}$ and $P_{\mathrm{SAT}}$. Free energies of aqueous substances formation at $P_{\mathrm{SAT}}$ (Amend and Shock, 2001; Marakushev and Belonogova, 2012, 2013) were used in calculations.

\begin{tabular}{|c|c|c|c|}
\hline (a) Reactions of cycle & $\Delta G_{298}^{0} \mathrm{~kJ} \mathrm{~mol}^{-1}$ & $\Delta G_{473}^{0} \mathrm{~kJ} \mathrm{~mol}^{-1}$ & \\
\hline 1. $(\mathrm{CH})_{2}(\mathrm{COOH})_{2}$ (fumarate $)+\mathrm{CH}_{4}=\left(\mathrm{CH}_{2}\right)\left(\mathrm{CH}_{3} \mathrm{CH}\right)(\mathrm{COOH})_{2}(2-$ methylsuccinate $)$ & -44.95 & -29.97 & $L$ \\
\hline 2. $\left(\mathrm{CH}_{2}\right)\left(\mathrm{CH}_{3} \mathrm{CH}\right)(\mathrm{COOH})_{2}+\mathrm{H}_{2} \mathrm{O}=\left(\mathrm{CH}_{3} \mathrm{CH}\right) \mathrm{CH}(\mathrm{OH})(\mathrm{COOH})_{2}$ (citramalate) $+\mathrm{H}_{2}$ & 96.57 & 94.14 & $H$ \\
\hline 3. $\left(\mathrm{CH}_{3} \mathrm{CH}\right) \mathrm{CH}(\mathrm{OH})(\mathrm{COOH})_{2}=\mathrm{CH}_{3} \mathrm{COOH}($ acetate $)+\mathrm{CH}_{3}(\mathrm{CO}) \mathrm{COOH}$ (pyruvate) & 19.35 & 1.73 & $H$ \\
\hline 4. $\mathrm{CH}_{3}(\mathrm{CO}) \mathrm{COOH}+\mathrm{CO}_{2}=\mathrm{CH}_{2} \mathrm{CO}(\mathrm{COOH})_{2}$ (oxaloacetate) & 13.11 & 35.03 & $L$ \\
\hline 5. $\mathrm{CH}_{2} \mathrm{CO}(\mathrm{COOH})_{2}+\mathrm{H}_{2}=\mathrm{CH}_{2} \mathrm{CH}(\mathrm{OH})(\mathrm{COOH})_{2}$ (malate) & -65.49 & -55.78 & $L$ \\
\hline 6. $\mathrm{CH}_{2} \mathrm{CH}(\mathrm{OH})(\mathrm{COOH})_{2}=(\mathrm{CH})_{2}(\mathrm{COOH})_{2}+\mathrm{H}_{2} \mathrm{O}$ & 5.68 & -5.26 & $H$ \\
\hline 7. $(\mathrm{CH})_{2}(\mathrm{COOH})_{2}$ (fumarate) $+\mathrm{H}_{2}=\left(\mathrm{CH}_{2}\right)_{2}(\mathrm{COOH})_{2}$ (succinate) & -102.24 & -88.88 & $L$ \\
\hline 8. $\left(\mathrm{CH}_{3} \mathrm{C}=\mathrm{CH}\right)(\mathrm{COOH})_{2}$ (mesaconate) $+\mathrm{H}_{2}=\left(\mathrm{CH}_{2}\right)\left(\mathrm{CH}_{3} \mathrm{CH}\right)(\mathrm{COOH})_{2}$ & -66.53 & -54.85 & $L$ \\
\hline (b) Oxidative reactions of cycle methane branch & $\Delta G_{298}^{0} \mathrm{~kJ} \mathrm{~mol}^{-1}$ & $\Delta G_{473}^{0} \mathrm{~kJ} \mathrm{~mol}^{-1}$ & \\
\hline$(\mathrm{CH})_{2}(\mathrm{COOH})_{2}$ (fumarate) $+\mathrm{CH}_{4}+\mathrm{H}_{2} \mathrm{O}=\mathrm{CH}_{3} \mathrm{COOH}$ (acetate) $+\mathrm{CH}_{3}(\mathrm{CO}) \mathrm{COOH}$ (pyruvate) $+\mathrm{H}_{2}$ & 70.97 & 65.9 & $H$ \\
\hline$(\mathrm{CH})_{2}(\mathrm{COOH})_{2}+\mathrm{CH}_{4}+0.5 \mathrm{O}_{2}=\mathrm{CH}_{3} \mathrm{COOH}+\mathrm{CH}_{3}(\mathrm{CO}) \mathrm{COOH}$ & -192.22 & -182.53 & $L$ \\
\hline$(\mathrm{CH})_{2}(\mathrm{COOH})_{2}+\mathrm{CH}_{4}+\mathrm{Fe}_{3} \mathrm{O}_{4}+1.5 \mathrm{SiO}_{2}=\mathrm{CH}_{3} \mathrm{COOH}+\mathrm{CH}_{3}(\mathrm{CO}) \mathrm{COOH}+1.5 \mathrm{Fe}_{2} \mathrm{SiO}_{4}$ & 45.08 & 25.21 & $H$ \\
\hline$(\mathrm{CH})_{2}(\mathrm{COOH})_{2}+\mathrm{CH}_{4}+3 \mathrm{Fe}_{2} \mathrm{O}_{3}=\mathrm{CH}_{3} \mathrm{COOH}+\mathrm{CH}_{3}(\mathrm{CO}) \mathrm{COOH}+2 \mathrm{Fe}_{3} \mathrm{O}_{4}$ & 22.38 & 13.87 & $H$ \\
\hline$(\mathrm{CH})_{2}(\mathrm{COOH})_{2}+\mathrm{CH}_{4}+0.75 \mathrm{FeS}_{2}+0.25 \mathrm{Fe}_{3} \mathrm{O}_{4}=\mathrm{CH}_{3} \mathrm{COOH}+\mathrm{CH}_{3}(\mathrm{CO}) \mathrm{COOH}+1.5 \mathrm{FeS}$ & 38.78 & 31.54 & $H$ \\
\hline$(\mathrm{CH})_{2}(\mathrm{COOH})_{2}+\mathrm{CH}_{4}+2 \mathrm{HNO}_{2}=\mathrm{CH}_{3} \mathrm{COOH}+\mathrm{CH}_{3}(\mathrm{CO}) \mathrm{COOH}+\mathrm{H}_{2} \mathrm{O}+2 \mathrm{NO}$ & -115.77 & -143.28 & $H$ \\
\hline$(\mathrm{CH})_{2}(\mathrm{COOH})_{2}+\mathrm{CH}_{4}+2 \mathrm{NO}=\mathrm{CH}_{3} \mathrm{COOH}+\mathrm{CH}_{3}(\mathrm{CO}) \mathrm{COOH}+\mathrm{N}_{2} \mathrm{O}$ & -274.7 & -250.83 & $L$ \\
\hline$(\mathrm{CH})_{2}(\mathrm{COOH})_{2}+\mathrm{CH}_{4}+\mathrm{NO}=\mathrm{CH}_{3} \mathrm{COOH}+\mathrm{CH}_{3}(\mathrm{CO}) \mathrm{COOH}+0.5 \mathrm{~N}_{2}$ & -276.93 & -264.48 & $L$ \\
\hline
\end{tabular}

the $\mathrm{C}-\mathrm{H}$ bond in methane $(439 \mathrm{~kJ})$ exceeds that of the $X-\mathrm{H}$ bond in other organic molecules, with the exception of the $\mathrm{O}-\mathrm{H}$ bond in $\mathrm{H}_{2} \mathrm{O}(497 \mathrm{~kJ})$ and other oxygenderived molecular species. In the field of alkane oxidation, enzymatic metal-oxo species promote $\mathrm{C}-\mathrm{H}$ activation through a metallo-radical pathway. This involves hydrogen radical abstraction from the alkane by the oxo species, followed by a rapid rebound of the radical species onto the metal hydroxo intermediate (Roudesly et al., 2017). The calculation of the potential energy surface showed the thermodynamic possibility of anaerobic oxidation of methane via fumarate addition, in a reaction catalyzed by the glycyl radical (Beasley and Nanny, 2012). The reaction mechanism fumarate $+\mathrm{CH}_{4} \rightarrow$ 2-methylsuccinate (Fig. 2) seems to be similar to the radical mechanism of breaking the $\mathrm{C}-\mathrm{H}$ bond with the formation of the $\mathrm{C}-\mathrm{C}$ bond, catalyzed by benzylsuccinate synthase (Buckel and Golding, 2006; Austin and Groves, 2011) during microbiological fixation of toluene by fumarate. Radicals of amino acids and dipeptides may be the possible catalysts of methane activation with the formation of methyl radical as an attacking agent. The formation of pyruvate and oxaloacetate in MF cycle (Fig. 2) indicates a very likely formation of amino acids in simple aqueous synthesis, for example, $\mathrm{C}_{3} \mathrm{H}_{4} \mathrm{O}_{3}$ (pyruvate) + $\mathrm{NH}_{3}=\mathrm{C}_{3} \mathrm{H}_{7} \mathrm{O}_{3} \mathrm{~N}$ (serine), $\quad \Delta G_{298}^{0}=-10,10 \mathrm{~kJ} \quad$ or pyruvate $+\mathrm{NH}_{3}+\mathrm{H}_{2}=\mathrm{C}_{3} \mathrm{H}_{7} \mathrm{NO}_{2}$ (alanine) $+\mathrm{H}_{2} \mathrm{O}$, and $\Delta G_{298}^{0}=-124,8 \mathrm{~kJ}$. Barge et al. (2019) show that pyruvate can form the alanine in hydrothermal systems in the presence of mixed-valence iron oxyhydroxides. Moreover, the generation of reactive oxygen species $\mathrm{H}_{2} \mathrm{O}_{2}$ and $\mathrm{OH}^{\circ}$ from minerals and $\mathrm{H}_{2} \mathrm{O}$ in anaerobic environments (e.g., Xian et al., 2019) creates the possibility of various radical mechanisms for the oxidation of substrates in a hydrothermal environment. According to Weiss et al. (2016), the LUCA metabolism had an excess of radical reaction mechanisms, which, in our opinion, could also participate in the reaction of $\mathrm{CH}_{4}$ fixation in the cycle, overcoming the activation barriers of kinetically unfavorable reaction steps.

Our understanding of the emergence of the methanotrophic metabolism is within the framework of the hydrothermal theory for the origin of life (e.g., Martin et al., 2008) with all its advantages (continuous flow of energy and matter, the temperature gradient, and great possibilities of homogeneous and heterogeneous metal catalysis). Before the occurrence of cellular structures, the primary autotrophic metabolism on the surface of minerals created the chemical space of competing autocatalytic carbon fixation cycles. The accumulation of "biomass" probably led to the emergence of heterotrophic protometabolism and the creation of a certain matrix of the organo-mineral system in which a cascade of protobiochemical redox reactions could occur, such as in the modern soils (Kéraval et al., 2016). Regardless of the specific mechanism of the functioning of the precellular autotrophic metabolism ("reductive surface pyrite world", Wächtershäuser, 1988; "hydrothermal reactor", Russell and Martin, 2004; “organo-mineral matrix”, Kéraval et al., 2016, and others), its origin and development were subject to the laws of aqueous thermodynamics.

\section{Anaerobic methane oxidation in the hydrothermal systems}

We represent the hydrothermal system in the form of a phase diagram which displays the chemical potential of oxygen vs. 


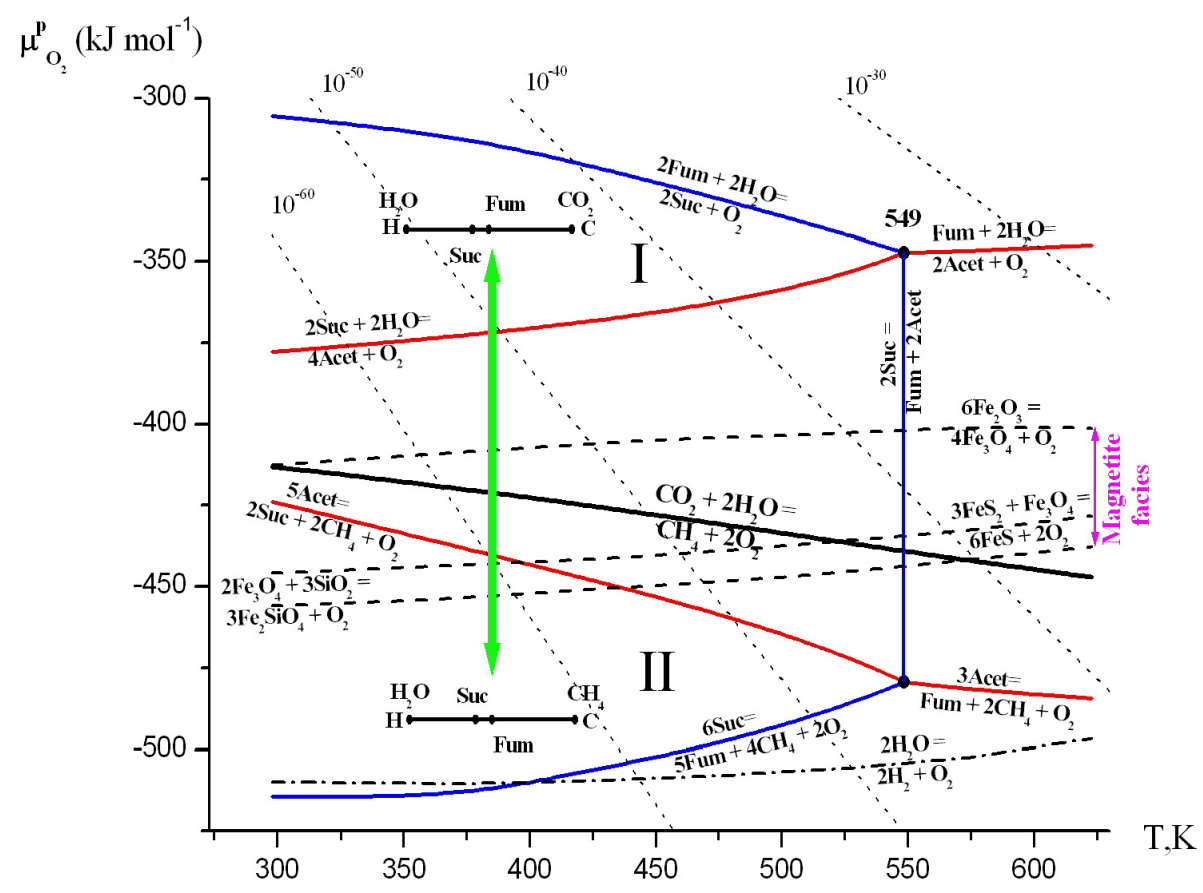

Figure 3. Diagram of the chemical potential of oxygen $\left(\mu_{\mathrm{O}_{2}}^{\mathrm{P}}\right)$ and temperature $(T, \mathrm{~K})$ at saturated vapor pressure $\left(P_{\mathrm{SAT}}\right)$. The areas of thermodynamic stability of substances and their parageneses were calculated according to the method described in Korzhinskii (1959) and Marakushev and Belonogova (2009). Points (indicated by temperature values) and lines represent four-phase and three-phase equilibria, separating the two-phase divariant fields of substance stabilities. The bold black line represents the equilibrium of $\mathrm{CO}_{2} \leftrightarrow \mathrm{CH}_{4}$ and separates their areas of thermodynamic stability (I and II). The dashed lines are equilibria of mineral buffers: hematite- $\mathrm{magnetite}, \mathrm{Fe}_{2} \mathrm{O}_{3} / \mathrm{Fe}_{3} \mathrm{O}_{4}(\mathrm{HM})$; pyrite-pyrrhotite-magnetite, $\mathrm{FeS}_{2}+\mathrm{Fe}_{3} \mathrm{O}_{4} / \mathrm{FeS}$ (PPM); and quartz-magnetite-fayalite, $\mathrm{SiO}_{2}+\mathrm{Fe}_{3} \mathrm{O}_{4} / \mathrm{Fe}_{2} \mathrm{SiO}_{4}(\mathrm{QMF})$. The isolines of the activity of $\mathrm{O}_{2}\left(10^{-n} \mathrm{M}\right.$, dotted lines) are drawn. The acetate and succinate facies are contoured with red and blue equilibria, respectively. We provide only two linear diagrams of the two-component $\mathrm{C}-\mathrm{H}$ system in the $\mathrm{CO}_{2}$ and $\mathrm{CH}_{4}$ facies. The transition between this facies with the change of chemical potential of oxygen is indicated by a green arrow. Abbreviations are as follows: succinate - Suc, fumarate - Fum and acetate - Acet.

temperature at saturated vapor pressure $\left(P_{\mathrm{SAT}}\right)$, where temperatures and pressures are below critical thresholds $(647.3 \mathrm{~K}$ and $22.1 \mathrm{MPa}$; Fig. 3). The chemical potentials $\left(\mu_{i}\right)$ of the components represent its partial energy, and the value $\mu_{i}$ is expressed through activity $\alpha_{i}$ or fugacity $f_{i}$ as follows: $\mu_{i}=\left(\mu_{i}^{0}\right)_{\mathrm{T}, \mathrm{p}}+R T \ln \alpha_{i}=\left(\mu_{i}^{0}\right)_{\mathrm{T}, \mathrm{p}}+R T \ln f_{i}$. Here numerical values depend on conventional standard states. For activity, the state of pure crystalline substance or unit molal concentration is usually considered as a standard state at a given temperature and pressure. In this state, $\alpha_{i}=1$, and hence $\mu_{i}=\left(\mu_{i}^{0}\right)_{\mathrm{T}, \mathrm{p}}$. The diagram is a two-component system (extensive parameters: $\mathrm{C}$ and $\mathrm{H}$ ), since oxygen become intensive parameters, like the temperature, and pressure. Oxygen is represented by the chemical potential of $\mathrm{O}_{2}$ in hydrothermal solution $\left(\mu_{\mathrm{O}_{2}}^{\mathrm{P}}=R T \ln a_{\mathrm{O}_{2}}\right.$, where $a_{\mathrm{O}_{2}}$ denotes the chemical activity of oxygen). According to Gibbs' phase rule, at arbitrary pressure, the nonvariant equilibria in the diagram (points) consist of four phases, and the three-phase equilibria (lines) divide the divariant stability fields (facies) of the two-phase equilibria.

The equilibrium $\mathrm{CH}_{4}+2 \mathrm{O}_{2}=\mathrm{CO}_{2}+2 \mathrm{H}_{2} \mathrm{O}$ (bold black line) divides the diagram into the facies of $\mathrm{CO}_{2}$ (I) and $\mathrm{CH}_{4}$ (II) (oxic and anoxic areas of the hydrothermal system) and illustrates the two main possibilities for the development of the $\mathrm{C}-\mathrm{H}-\mathrm{O}$ system in the facies carbon dioxide or methane. Intermediates of the MF cycle are acetate, succinate and fumarate, and we considered their metastable equilibria and parageneses. In all phase space under consideration, there are fumarate facies. The equilibrium of $5 \mathrm{Fum}+4 \mathrm{CH}_{4}+$ $2 \mathrm{O}_{2}=6 \mathrm{Suc}$ at low temperatures (Fig. 3) is located in the region of very low partial pressures of oxygen, whereas the equilibrium of Fum $+2 \mathrm{CH}_{4}+\mathrm{O}_{2}=3 \mathrm{Acet}$ at high temperatures occurs in facies of high pressures. Acetate and succinate facies (contoured with red and blue equilibria, respectively) completely encompass the equilibrium of $\mathrm{CH}_{4}+\mathrm{O}_{2}=\mathrm{CO}_{2}+$ $\mathrm{H}_{2} \mathrm{O}$. That is, in the hydrothermal solution, the parageneses of some components within the MF cycle are stable in both the $\mathrm{CO}_{2}$ and the $\mathrm{CH}_{4}$ facies. The whole system can develop in either of the two directions as the chemical potential of oxygen changes: (1) the formation of low-temperature (Suc$\left.\mathrm{H}_{2} \mathrm{O}\right)$ and high-temperature $\left(\mathrm{Fum}-\mathrm{H}_{2} \mathrm{O}\right)$ paragenesis in $\mathrm{CO}_{2}$ facies (I) and (2) the formation of low-temperature (Suc$\left.\mathrm{CH}_{4}\right)$ and high-temperature (Fum- $\left.\mathrm{CH}_{4}\right)$ paragenesis in $\mathrm{CH}_{4}$ facies (II). Thus, within these facies, protobiochemical sys- 
tems supporting carbon fixation in the form of $\mathrm{CO}_{2}$ or $\mathrm{CH}_{4}$ can develop, and methane facies (II) represent a broad area of $\mathrm{CH}_{4}$ assimilation by carboxylic acids in an aqueous environment. The high stability of the succinate-fumarate-acetate paragenesis in hydrothermal systems at $200^{\circ} \mathrm{C}(473 \mathrm{~K})$ was experimentally shown (Estrada et al., 2017).

Mineral buffers of up to $549 \mathrm{~K}$ are located in the facies of succinate, but the equilibrium of HM remains in the area of thermodynamic $\mathrm{CO}_{2}$ stability (facies I), and pyritepyrrhotite-magnetite (PPM) and quartz-magnetite-fayalite (QMF) equilibria occur in methane facies II and intersect the fundamental equilibrium of $2 \mathrm{Suc}+2 \mathrm{CH}_{4}+\mathrm{O}_{2}=5 \mathrm{Acet}$. Magnetite $\left(\mathrm{Fe}_{3} \mathrm{O}_{4}\right)$ facies (between $\mathrm{HM}$ and QMF equilibria) encompass $\mathrm{CH}_{4} / \mathrm{CO}_{2}$ equilibrium in nearly the entire temperature range of the hydrothermal system under consideration. Thus, the redox areas of magnetite stability correspond to the formation conditions both $\mathrm{CO}_{2}$ - and $\mathrm{CH}_{4}$-assimilating systems. The presence of magnetite in the early Archean ocean was shown by Li et al. (2017). Shibuya et al. (2016) also conclude that iron redox reactions probably played an important role in the early evolution of methanotrophic metabolisms in the Hadean alkaline hydrothermal system. The QMF buffer equilibrium is completely located in the methane facies (I), which, according to data (Yang et al., 2014), corresponds on average to the redox conditions of the Hadean mantle and crust. Up to 3.6 billion years ago and maybe even to the great oxidative event of 2.2-2.4 billion years ago, on the Earth's surface, the oxidation potential of the magnetite redox pairs apparently determined the chemical potential of environmental oxygen.

\section{Conclusion}

The cyclic planetary fluid flows (outgassing of volatiles from mantle) drive Earth's chemical evolution, leading to the formation of different geobiochemical systems of carbon fixation. Impulses of $\mathrm{CO}_{2}$ and $\mathrm{CH}_{4}$ degassing on our planet must have determined the preference of specific autotrophic carbon fixation metabolism development. It is widely accepted that autotrophic metabolism is the fixation of inorganic carbon solely in the form of $\mathrm{CO}_{2}$, but the origin of methane, both on the ancient Earth and on the planets and satellites (for example, on Titan), is clearly inorganic; therefore, carbon fixation from methane is also a manifestation of autotrophic metabolism (formation of organic compounds from inorganic precursors).

The variety of modern autotrophic carbon fixation seems to be created by the association of the different metabolic associations and modules that, apparently, could function in the ancestral systems of the anaerobic fixation of $\mathrm{CH}_{4}$. When approximately $\sim 3.6$ billion years (Yang et al., 2014), a $\mathrm{CO}_{2}$ degassing regime became dominant on our planet, the relic methanotrophy systems were forced to die out or be thrown into unusual and extreme ecological niches. If we consider LUCA to be a relatively recent player in the evolution of life (Cornish-Bowden and Cárdenas, 2017), the ancestral metabolic systems of carbon fixation in putative preLUCA could differ appreciably from modern ones.

In the process of development of $\mathrm{CO}_{2}$ fixation systems on the Earth, the main problem was the presence of electron donors (therefore, evolution created selective reducing agents: NADH, NADPH and FADH), whereas the fixation of $\mathrm{CH}_{4}$ essentially depended on the presence of electron acceptors. The oxygen-containing nitrogen compounds are the best oxidants in the hydrothermal systems, but their presence there is unlikely. Nevertheless, the redox pairs of hematite-magnetite and quartz-magnetite-fayalite create a specific area of chemical potential of oxygen that satisfies the thermodynamic requirements of oxidation and assimilation of methane by protometabolic pathways. Hydrothermal systems of ancient Earth may have been very similar to those that currently exist on some extraterrestrial cosmic bodies, such as Europa or Enceladus. The degassing of these cosmic bodies can currently support methane metabolism, but the problem is knowing if there are electron acceptors there (Russell et al., 2017).

Data availability. Data used for the composition of this paper are available upon request from Sergey A. Marakushev (shukaram@yandex.ru).

Author contributions. SAM developed the concept, created the model, and prepared the paper with contributions from OVB, who performed thermodynamic calculations.

Competing interests. The authors declare that they have no conflict of interest.

Acknowledgements. The authors are grateful to the editor Sébastien Fontaine and the three anonymous reviewers for their constructive criticism and valuable advice that significantly improved the paper.

Review statement. This paper was edited by Sébastien Fontaine and reviewed by three anonymous referees.

\section{References}

Alldredge, L. R.: A discussion of impulses and jerks in the geomagnetic field, J. Geophys. Res., 89, 4403-4412, https://doi.org/10.1029/JB089iB06p04403, 1984.

Amend, J. P. and Shock, E. L.: Energetics of overall metabolic reactions of thermophilic and hyperthermophilic $\mathrm{Ar}$ chaea and Bacteria, FEMS Microbiol. Rev., 25, 175-243, https://doi.org/10.1016/S0168-6445(00)00062-0, 2001. 
Aubert, J., Tarduno, J. A., and Johnson, C. L.: Observations and models of the long-term evolution of earth's magnetic field, Space Sci. Rev., 155, 337-370, https://doi.org/10.1007/s11214010-9684-5, 2010.

Aulbach, S., Woodland, A. B., Vasilyev, P., Galvez, M. E., and Viljoen K. S.: Effects of low-pressure igneous processes and subduction on $\mathrm{Fe}^{3+} / \mathrm{ZFe}$ and redox state of mantle eclogites from Lace (Kaapvaal craton), Earth Planet. Sc. Lett., 474, 283-295, 2017.

Austin, R. N. and Groves, J. T.: Alkane-oxidizing metallo enzymes in the carbon cycle, Metallomics, 3, 775-787, https://doi.org/10.1039/c1mt00048a, 2011.

Balashov, Y. A. and Glaznev, V. N.: Cycles of alkaline magmatism, Geochem. Int., 44, 274-285, https://doi.org/10.1134/S0016702906030050, 2006.

Barge, L. M., Flores, E., Baum, M. M., VanderVelde, D. G., and Russell, M. J.: Redox and $\mathrm{pH}$ gradients drive amino acid synthesis in iron oxyhydroxide mineral systems, P. Natl. Acad. Sci. USA, 116, 4828-4833, https://doi.org/10.1073/pnas.1812098116, 2019.

Beal, E. J., House, C. H., and Orphan, V. J.: Manganese- and irondependent marine methane oxidation, Science, 325, 184-187, https://doi.org/10.1126/science.1169984, 2009.

Beasley, K. K. and Nanny M. A.: Potential energy surface for anaerobic oxidation of methane via fumarate addition, Environ. Sci. Technol., 46, 8244-8252, https://doi.org/10.1021/es3009503, 2012.

Boehnkea, P., Bell, E. A., Stephana, T., Trappitscha, R., Keller, C. B., Pardo, O. S., Davis, A. M., Harrisonc, T. M., and Pellina, M.: Potassic, high-silica Hadean crust, P. Natl. Acad. Sci. USA, 115, 6353-6356, https://doi.org/10.1073/pnas.1720880115, 2018.

Bouquet, A., Mousis, O., Waite, J. H., and Picaud, S.: Possible evidence for a methane source in Enceladus' ocean, Geophys. Res. Lett., 42, 1334-1339, https://doi.org/10.1002/2014GL063013, 2015.

Braakman, R. and Smith, E.: The emergence and early evolution of biological carbon-fixation, PLOS Comput. Biol., 8, 1-16, https://doi.org/10.1371/journal.pcbi.1002455, 2012.

Braakman, R. and Smith, E.: The compositional and evolutionary logic of metabolism, Phys. Biol., 10, 1-63, https://doi.org/10.1088/1478-3975/10/1/011001, 2013.

Brovarone, A. V., Martinez I., Elmaleh A., Compagnoni, R., Chaduteau, C., Ferraris, C., and Esteve, I.: Massive production of abiotic methane during subduction evidenced in metamorphosed ophicarbonates from the Italian Alps, Nat. Commun., 8, 14134, https://doi.org/10.1038/ncomms14134, 2017.

Buckel, W. and Golding, B. T.: Radical enzymes in anaerobes, Annu. Rev. Microbiol., 60, 27-49, https://doi.org/10.1146/annurev.micro.60.080805.142216, 2006.

Cornish-Bowden, A. and Cárdenas, M. L.: "Life Before LUCA", J. Theor. Biol., 434, 68-74, https://doi.org/10.1016/j.jtbi.2017.05.023, 2017.

Estrada, C. F., Mamajanov, I., Hao, J., Sverjensky, D. A., Cody, G. D., and Hazen, R. M.: Aspartate transformation at $200^{\circ} \mathrm{C}$ with brucite $\left[\mathrm{Mg}(\mathrm{OH})_{2}\right], \mathrm{NH}_{3}$, and $\mathrm{H}_{2}$ : implications for prebiotic molecules in hydrothermal systems, Chem. Geol., 457, 162172, https://doi.org/10.1016/j.chemgeo.2017.03.025, 2017.
Etiope, G. and Sherwood Lollar, B.: Abiotic methane on Earth, Rev. Geophys., 51, 276-299, https://doi.org/10.1002/rog.20011, 2013.

Ettwig, K. F., Butler, M. K., Le Paslier, D., Pelletier, E., Mangenot, S., Kuypers, M. M., Schreiber, F., Dutilh, B. E., Zedelius, J., de Beer, D., Gloerich, J., Wessels, H. J., van Alen, T., Luesken, F., Wu, M. L., van de Pas-Schoonen, K. T., Op den Camp, H. J., Janssen-Megens, E. M., Francoijs, K. J., Stunnenberg, H., Weissenbach, J., Jetten, M. S., and Strous, M.: Nitrite-driven anaerobic methane oxidation by oxygenic bacteria, Nature, 464, 543548, https://doi.org/10.1038/nature08883, 2010.

Ettwig, K. F., Zhu, B., Speth, D., Keltjens, J. T., Jetten, M. S. M., and Kartal, B.: Archaea catalyze iron-dependent anaerobic oxidation of methane, P. Natl. Acad. Sci. USA, 113, 12792-12796, https://doi.org/10.1073/pnas.1609534113, 2016.

Fuchs, G.: Alternative pathways of carbon dioxide fixation: Insights into the early evolution of life?, Annu. Rev. Microbiol., 65, 631-658, https://doi.org/10.1146/annurev-micro090110-102801, 2011.

Haroon, M. F., Hu, S., Shi, Y., Imelfort, M., Keller, J., Hugenholtz, P., Yuan, Z., and Tyson, G. W.: Anaerobic oxidation of methane coupled to nitrate reduction in a novel archaeal lineage, Nature, 500, 567-570, https://doi.org/10.1038/nature12375, 2013.

Haynes, C. A. and Gonzalez, R.: Rethinking biological activation of methane and conversion to liquid fuels, Nat. Chem. Biol., 10, 331-339, https://doi.org/10.1038/nchembio.1509, 2014.

He, Z., Zhang, Q., Feng, Y., Luo, H., Pan, X., and Gadd, G. M.: Microbiological and environmental significance of metal-dependent anaerobic oxidation of methane, Sci. Total Environ., 610-611, 759-768, https://doi.org/10.1016/j.scitotenv.2017.08.140, 2018.

Hinrichs, K. U., Hayes, J. M., Sylva, S. P., Brewer, P. G., and DeLong, E. F.: Methane-consuming archaebacteria in marine sediments, Nature, 398, 802-805, https://doi.org/10.1016/S01466380(00)00106-6, 1999.

Kéraval, B., Lehours, A. C., Colombet, J., Amblard, C., Alvarez, G., and Fontaine, S.: Soil carbon dioxide emissions controlled by an extracellular oxidative metabolism identifiable by its isotope signature, Biogeosciences, 13, 6353-6362, https://doi.org/10.5194/bg-13-6353-2016, 2016.

Knittel, K. and Boetius, A.: Anaerobic oxidation of methane: progress with an unknown process. Annu. Rev. Microbiol., 63, 311-334, https://doi.org/10.1146/annurev.micro.61.080706.093130, 2009.

Kolesnikov, A., Kutcherov, V. G., and Goncharov, A. F.: Methanederived hydrocarbons produced under upper-mantle conditions, Nat. Geosci. 2, 566-570, https://doi.org/10.1038/ngeo591, 2009.

Korzhinskii, D. S.: Physicochemical basis of the analysis of the paragenesis of minerals, Consultants Bureau, Inc., New York, USA, and Chapman \& Hall, London, UK, 1959.

Larson, R. L. and Olson, P.: Mantle plumes control magnetic reversal frequency, Earth Planet. Sc. Lett., 107, 437-447, https://doi.org/10.1016/0012-821X(91)90091-U, 1991.

Li, Y.-L., Konhauser, K. O., and Zhai, M.: The formation of magnetite in the early Archean oceans, Earth Planet. Sc. Lett., 466, 103-114, https://doi.org/10.1016/j.eps1.2017.03.013, 2017.

Lorenz, D. M., Jeng, A., and Deem, M. W.: The emergence of modularity in biological systems, Phys. Life Rev., 8, 129-160, https://doi.org/10.1016/j.plrev.2011.02.003, 2011. 
Marakushev, A. A. and Marakushev, S. A.: PT facies of elementary, hydrocarbon, and organic substances, Dokl. Earth Sci., 406, 141147, https://doi.org/10.1134/S1028334X0601034X, 2006.

Marakushev, A. A. and Marakushev, S. A.: Formation of oil and gas fields, Lithol. Miner. Resour., 43, 454-469, https://doi.org/10.1134/S0024490208050039, 2008

Marakushev, A. A. and Marakushev, S. A.: Fluid evolution of the Earth and origin of the biosphere, in: Man and the Geosphere, edited by: Florinsky, I. V., Nova Science Publishers Inc, New York, USA, 3-31, 2010.

Marakushev, S. A. and Belonogova, O. V.: The parageneses thermodynamic analysis of chemoautotrophic $\mathrm{CO}_{2}$ fixation archaic cycle components, their stability and self-organization in hydrothermal systems, J. Theor. Biol., 257, 588-597, https://doi.org/10.1016/j.jtbi.2008.11.032, 2009.

Marakushev, S. A. and Belonogova, O. V.: Metabolic design and biomimetic catalysis of the archaic chemoautotrophic $\mathrm{CO}_{2}$ fixation cycle, Mos. Univer. Chem. Bull., 65, 212-218, https://doi.org/10.3103/S0027131410030211, 2010.

Marakushev, S. A. and Belonogova, O. V.: Thermodynamic factors of natural selection in autocatalytic chemical systems, Dokl. Biochem. Biophys., 444, 131-136, https://doi.org/10.1134/S1607672912030015, 2012.

Marakushev, S. A. and Belonogova, O. V.: The divergence and natural selection of autocatalytic primordial metabolic systems, Orig. Life Evol. Biosph., 43, 263-281, https://doi.org/10.1007/s11084013-9340-7, 2013.

Marakushev, S. A. and Belonogova, O. V.: The Chemical Potentials of Hydrothermal Systems and the Formation of Coupled Modular Metabolic Pathways, Biophysics, 60, 542-552, https://doi.org/10.1134/S0006350915040168, 2015.

Martin, W., Baross, J., Kelley, D., and Russell, M. J.: Hydrothermal vents and the origin of life, Nat. Rev. Microbiol., 6, 805-814, https://doi.org/10.1038/nrmicro1991, 2008.

Martin, W. F., Weiss, M. C., Neukirchen, S., Nelson-Sathi, S., and Sousa, F. L.: Physiology, phylogeny, and LUCA, Microbial Cell, 3, 582-587, https://doi.org/10.15698/mic2016.12.545, 2016.

Martinez-Cruz, K., Leewis, M.-C., Herriott, I. C., SepulvedaJauregui, A., Anthony, K. W., Thalasso, F., and Leigh, M. B.: Anaerobic oxidation of methane by aerobic methanotrophs in sub-Arctic lake sediments, Sci. Total Environ., 607-608, 23-31, https://doi.org/10.1016/j.scitotenv.2017.06.187, 2017.

McCollom, T. M.: Laboratory simulations of abiotic hydrocarbon formation in Earth's deep subsurface, Rev. Mineral. Geochem., 75, 467-494, https://doi.org/10.2138/rmg.2013.75.15, 2013.

McGlynn, S. E.: Energy metabolism during anaerobic methane oxidation in ANME Archaea, Microbes Environ., 32, 5-13, https://doi.org/10.1264/jsme2.ME16166, 2017.

Mével, C.: Serpentinization of abyssal peridotites at mid-ocean ridges, C. R. Geosci., 335, 825-852, https://doi.org/10.1016/j.crte.2003.08.006, 2003.

Muchowska, K. B., Varma, S. J., Chevallot-Beroux, E., LethuillierKarl, L., Li, G., and Moran, J.: Metals promote sequences of the reverse Krebs cycle, Nat. Ecol. Evol., 1, 1716-1721, https://doi.org/10.1038/s41559-017-0311-7, 2017.

Musat, F.: The anaerobic degradation of gaseous, nonmethane alkanes - From in situ processes to microorganisms, Comput. Struct. Biotech. J., 13 222-228, https://doi.org/10.1016/j.csbj.2015.03.002, 2015.
Nitschke, W. and Russell, M. J.: Beating the acetyl-CoA pathway to the origin of life, Philos. T. Roy. Soc. B., 368, 20120258, https://doi.org/10.1098/rstb.2012.0258, 2013.

Nivin, V. A., Treloar, P. J., Konopleva, N. G., and Ikorsky, S. V.: A review of the occurrence, form and origin of C-bearing species in the Khibiny alkaline igneous complex, Kola Peninsula, NW Russia, Lithos, 85, 93-112, https://doi.org/10.1016/j.lithos.2005.03.021, 2005.

Oehler, D. Z. and Etiope, G.: Methane seepage on Mars: where to look and why, Astrobiology, 17, 1233-1264, https://doi.org/10.1089/ast.2017.1657, 2017.

Oni, O. E. and Friedrich, M. W.: Metal oxide reduction linked to anaerobic methane oxidation, Trends Microbiol., 25, 88-90, https://doi.org/10.1016/j.tim.2016.12.001, 2017.

Potter, J. and Konnerup-Madsen, J.: A review of the occurrence and origin of abiogenic hydrocarbons in igneous rocks, in: Hydrocarbons in Crystalline Rocks, edited by: Petford, N. and McCaffrey, K. J. W., Special Publications, 214, Geological Society, London, 151-173, https://doi.org/10.1144/GSL.SP.2003.214.01.10, 2003.

Roudesly, F., Oble, J., and Poli, G.: Metal-catalyzed C-H activation/functionalization: The fundamentals, J. Mol. Catal. A-Chem., 426, 275-296, https://doi.org/10.1016/j.molcata.2016.06.020, 2017.

Russell, M. J. and Martin, W.: The rocky roots of the acetyl-CoA pathway, Trends Biochem. Sci., 29, 358-363, https://doi.org/10.1016/j.tibs.2004.05.007, 2004.

Russell, M. J., Murray, A. E., and Kevin, P. H.: The possible emergence of life and differentiation of a shallow biosphere on irradiated icy worlds: The example of Europa, Astrobiololgy, 17, 1265-1273, https://doi.org/10.1089/ast.2016.1600, 2017.

Russell, M. J. and Nitschke, W.: Methane: Fuel or Exhaust at the Emergence of Life?, Astrobiology, 17, 1053-1066, https://doi.org/10.1089/ast.2016.1599, 2017.

Scheller, S., Goenrich, M., Boecher, R., Thauer, R. K., and Jaun, B.: The key nickel enzyme of methanogenesis catalyses the anaerobic oxidation of methane, Nature, 465, 606-609, https://doi.org/10.1038/nature09015, 2010.

Schopf, J. W., Kitajima, K., Spicuzza M. J., Kudryavtsev A. B., and Valley, J. W.: SIMS analyses of the oldest known assemblage of microfossils document their taxon-correlated carbon isotope compositions, P. Natl. Acad. Sci. USA, 115, 53-58, https://doi.org/10.1073/pnas.1718063115, 2017.

Schreiber, U., Mayer, C., Schmitz, O. J., Rosendahl, P., Bronja, A., Greule, M., Keppler, F., Mulder, I., Sattler, T., and Schöler, H. F.: Organic compounds in fluid inclusions of Archean quartz, Analogues of prebiotic chemistry on early Earth, PLoS ONE, 12, e0177570, https://doi.org/10.1371/journal.pone.0177570, 2017.

Schulte, M., Blake, D., Hoehler, T., and McCollom, T.: Serpentinization and its implications for life on the early Earth and Mars, Astrobiology, 6, 364-376, https://doi.org/10.1089/ast.2006.6.364, 2006.

Scott, H. P., Hemley, R. J., and Mao, H.: Generation of methane in the Earth's mantle: in situ high pressure-temperature measurements of carbonate reduction, P. Natl Acad. Sci. USA, 101, 14023-14026, https://doi.org/10.1073/pnas.0405930101, 2004.

Semrau, J. D., DiSpirito, A. A., and Murrell, J. C.: Life in the extreme: thermoacidophilic methanotrophy, Trends Microbiol., 16, 190-193, https://doi.org/10.1016/j.tim.2008.02.004, 2008. 
Shibuya, T., Russell, M. J., and Takai, K.: Free energy distribution and hydrothermal mineral precipitation in Hadean submarine alkaline vent systems: Importance of iron redox reactions under anoxic conditions, Geochim. Cosmochim. Ac., 175, 1-19, https://doi.org/10.1016/j.gca.2015.11.021, 2016.

Smejkalová, H., Erb, T. J., and Fuchs, G.: Methanol assimilation in Methylobacterium extorquens AM1: demonstration of all enzymes and their regulation, PLoS ONE, 5, e13001, https://doi.org/10.1371/journal.pone.0013001, 2010.

Smit, K. V., Shirey, S. B., Stern, R. A., Steele, A., and Wang, W.: Diamond growth from $\mathrm{C}-\mathrm{H}-\mathrm{N}-\mathrm{O}$ recycled fluids in the lithosphere: Evidence from $\mathrm{CH}_{4}$ micro-inclusions and $\delta^{13 \mathrm{C}}-\delta^{15} \mathrm{~N}-\mathrm{N}$ content in Marange mixed-habit diamonds, Lithos, 265, 68-81, https://doi.org/10.1016/j.lithos.2016.03.015, 2016.

Smith, E. and Morowitz, H. G.: Universality in intermediary metabolism, P. Natl. Acad. Sci. USA, 101, 13168-13173, https://doi.org/10.1073/pnas.0404922101, 2004.

Soo, V. W. C., McAnulty, M. J., Tripathi, A., Zhu, F., Zhang, L., Smith, P. B., Hatzakis, E., Agrawal, S., Nazem-Bokaee, H., Gopalakrishnan, S., Salis, H. S., Ferry, J. G., Maranas, C. D., Patterson, A. D., and Wood, T. K.: Reversing methanogenesis to capture methane for liquid biofuel precursors, Microb. Cell Fact., 15, 11-25, https://doi.org/10.1186/s12934-015-0397-z, 2016.

Tao, R., Zhang, L., Tian, M., Zhu, J., Liu, X., Liu, J., Höfer, H. E., Stagno, V., and Fei, Y.: Formation of abiotic hydrocarbon from reduction of carbonate in subduction zones: Constraints from petrological observation and experimental simulation, Geochim. Cosmochim. Ac., 239, 390-408, https://doi.org/10.1016/j.gca.2018.08.008, 2018.

Tarduno, J. A., Cottrel, R. D., Davis, W. J., Nimmo, F., and Bono, R. K.: A Hadean to Paleoarchean geodynamo recorded by single zircon crystals, Science, 349, 521-524, https://doi.org/10.1126/science.aaa9114, 2015.

Thauer, R. K. and Shima, S.: Methane as fuel for anaerobic microorganisms, Ann. NY Acad. Sci., 1125, 158-170, https://doi.org/10.1196/annals.1419.000, 2008.

Tian, F., Toon, O. B., Pavlov, A. A., and De Sterck, H.: A hydrogen-rich early Earth atmosphere, Science, 308, 1014-1017, https://doi.org/10.1126/science.1106983, 2005.
Timmers, P. H. A., Welte, C. U., Koehorst, J. J., Plugge, C. M., Jetten, M. S. M., and Stams, A. J. M.: Reverse methanogenesis and respiration in methanotrophic archaea, Archaea, 2017, 1-22, https://doi.org/10.1155/2017/1654237, 2017.

Tobie, G., Lunine, J. I., and Sotin, C.: Episodic outgassing as the origin of atmospheric methane on Titan, Nature, 440, 61-64, https://doi.org/10.1038/nature04497, 2006.

Touret, J. L. R.: Remnants of early Archaean hydrothermal methane and brines in pillow-breccia from the IsuaGreenstone Belt, West Greenland, Precambrian Res., 126, 219233, https://doi.org/10.1016/S0301-9268(03)00096-2, 2003.

Wächtershäuser, G.: Before enzymes and templates: theory of surface metabolism, Microbiol. Rev. 52, 452-484, https://doi.org/10.1101/cshperspect.a002162, 1988.

Wächtershäuser, G.: Evolution of the first metabolic cycles, P. Natl. Acad. Sci. USA, 87, 200-204, https://doi.org/10.1073/pnas.87.1.200, 1990.

Wang, D. T., Reeves, E. P., McDermott, J. M., Seewald, J. S., and Ono, S.: Clumped isotopologue constraints on the origin of methane at seafloor hot springs, Geochim. Cosmochim. Ac., 223, 141-158, https://doi.org/10.1016/j.gca.2017.11.030, 2018.

Weiss, M. C., Sousa, F. L., Mrnjavac, N., Neukirchen, S., Roettger, M., Nelson-Sathi, S., and Martin W. F.: The physiology and habitat of the last universal common ancestor, Nat. Microbiol., 1, 1-8 , https://doi.org/10.1038/NMICROBIOL.2016.116, 2016.

Xian, H., Zhu, J., Tan W., Tang, H., Liu, P., Zhu, R., Liang, X., Wei, J. B., He, H., and Teng, H. H.: The mechanism of defect induced hydroxylation on pyrite surfaces and implications for hydroxyl radical generation in prebiotic chemistry, Geochim. Cosmochim. Ac., 244, 163-172, https://doi.org/10.1016/j.gca.2018.10.009, 2019.

Yang, X., Gaillard, F., and Scaillet, B.: A relatively reduced Hadean continental crust and implications for the early atmosphere and crustal rheology, Earth Planet. Sc. Lett., 393, 210-219, https://doi.org/10.1016/j.epsl.2014.02.056, 2014.

Zahnle, K. J., Gacesa, M., and Catling, D. C.: Strange messenger: A new history of hydrogen on Earth, as told by Xenon, Geochim. Cosmochim. Ac., 244, 56-85, https://doi.org/10.1016/j.gca.2018.09.017, 2019. 